\title{
触 New Disease Reports \\ First report of Schizophyllum commune associated with apple wood rot in Tunisia
}

A. Lahbib ${ }^{1}$, M. Chattaoui ${ }^{2}$, N. Aydi ${ }^{3}$, H. Zaghouani ${ }^{3}$, O. Beldi ${ }^{3}$, M. Daami-Remadi $^{4}$ and B. Nasraoui ${ }^{1}$

${ }^{1}$ Bioagressors and Integrated Protection in Agriculture, National Agronomic Institute of Tunisia, University of Carthage, 1082, Tunis, Tunisia; ${ }^{2}$ Laboratory for the Improvement and Protection of Olive Genetic Resources, BP 208, Mahrajene City, 1082, Tunis, Tunisia; ${ }^{3}$ Laboratory for the Control of Plant Diseases, Ministry of Agriculture and Environment, 1002, Tunis, Tunisia; ${ }^{4}$ Integrated Horticultural Production in the Tunisian Centre-East, Regional Centre of Research on Horticulture and Organic Agriculture, University of Sousse, 4042, Chott-Mariem, Tunisia

*E-mail: amira.lahbib@gmail.com

Received: 14 Nov 2016. Published: 05 Dec 2016. Keywords: dieback, fungus, ITS

During 2013-2014, an emerging disease was observed on apple (Malus domestica) trees leading to significant damage in Tunisia. This problem was particularly widespread in the region of Kasserine, the largest appleproducing region in Tunisia, where $80 \%$ of the orchards were affected. Diseased trees exhibited symptoms of severe dieback associated with wood rot. Masses of carpophores on twigs, scaffold branches and trunks, as well as bark darkening and necrotic leaves were observed (Fig. 1).

Samples of infected twigs and leaves were collected and brought in plastic bags to the laboratory. They were disinfected with $70 \%$ ethanol for one minute, rinsed in sterile distilled water and air-dried. Small pieces were removed from lesion margins and placed on malt extract agar (MEA) medium. Plates were incubated at $25^{\circ} \mathrm{C}$ under fluorescent light $(12 \mathrm{~h} /$ day $)$. Developing fungal colonies showed a white cottony mycelium and fanshaped fruiting bodies after 65 days incubation (Fig. 2). Based on their macro- and micro-morphological traits, isolates were identified as Schizophyllum commune (Latham, 1970; Bergdahl \& French, 1985; Takemoto et al., 2010).

A pathogenicity test of one representative isolate was performed on detached apple stems $(20 \mathrm{~cm}$ in length). Stems were surface sterilised for one minute with $70 \%$ alcohol and air-dried. They were wounded using a sterilised scalpel and inoculated with mycelial plugs $(6 \mathrm{~mm}$ in diameter) which had been removed from the margin of a culture actively growing on MEA. Inoculated stem sections were sealed with paraffin film to prevent desiccation. Control stem sections were inoculated with MEA plugs only. Both inoculated and control stems were incubated in moist chambers maintained at $25^{\circ} \mathrm{C}$ and $95 \%$ relative humidity. After 30 days incubation, all inoculated stems developed symptoms similar to those observed under field conditions whereas control ones remained healthy. The pathogen was consistently re-isolated from symptomatic stems thereby fulfilling Koch's postulates.

For molecular identification, DNA from five isolates was extracted according to the protocol of Mahuku (2004) and the ITS region was amplified using ITS1F and ITS4 primers. Amplicons of the expected size were sequenced (GenBank Accession Nos. KX555521-KX555525) and showed 99\% identity with S. commune isolates KP326577 and KJ093499. Schizophyllum commune is a sap-rot basidiomycete and has also been reported as a plant pathogen of living trees including apple (Takemoto et al., 2010), citrus (Russo et al., 2012) and olive (Úrbez-Torres et al., 2012). To our knowledge, this is the first report of $S$. commune causing wood rot on apple trees in Tunisia.

\section{References}

Bergdahl DR, French DW, 1985. Association of wood decay fungi with decline and mortality of apple trees in Minnesota. Plant Disease 69, 887-890. http://dx.doi.org/10.1094/PD-69-887

Latham AJ, 1970. Development of apple fruit rot and basidiocarp formation by Schizophyllum commune. Phytopathology 60, 596-598. http://dx.doi.org/10.1094/Phyto-60-596

Mahuku GS, 2004. A simple extraction method suitable for PCR-based analysis of plant, fungal, and bacterial DNA. Plant Molecular Biology Reporter 22, 71-81. http://dx.doi.org/10.1007/BF02773351

Russo M, Licciardello G, Bella P, 2012. Unusual occurrence of Schizophyllum commune on young topgrafted citrus. Journal of Plant Pathology 94, S4.77.

Takemoto S, Nakamura H, Imamura Y, Shimane T, 2010. Schizophyllum commune as a ubiquitous plant parasite. Japan Agricultural Research Quarterly 44, 357-364. http://dx.doi.org/10.6090/jarq.44.357

Úrbez-Torres JR, Peduto F, Vossen PM, Krueger WH, Gubler WD, 2012. Olive twig and branch dieback: Etiology, incidence, and distribution in California. Plant Disease 97, 231-244.

http://dx.doi.org/10.1094/PDIS-04-12-0390-RE

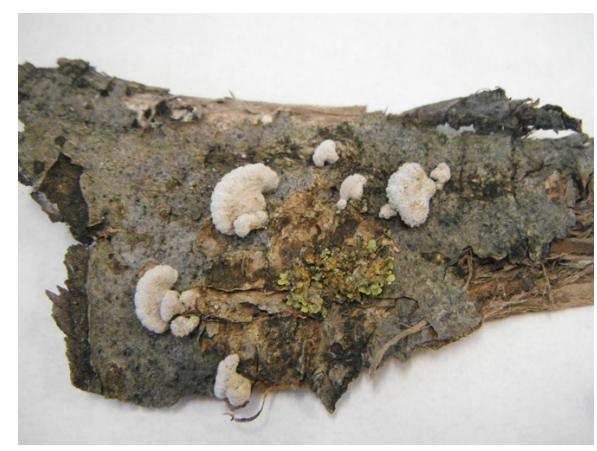

Figure 1

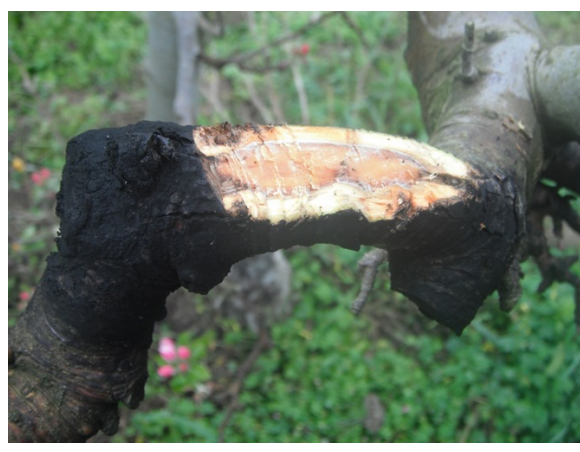

Figure 2

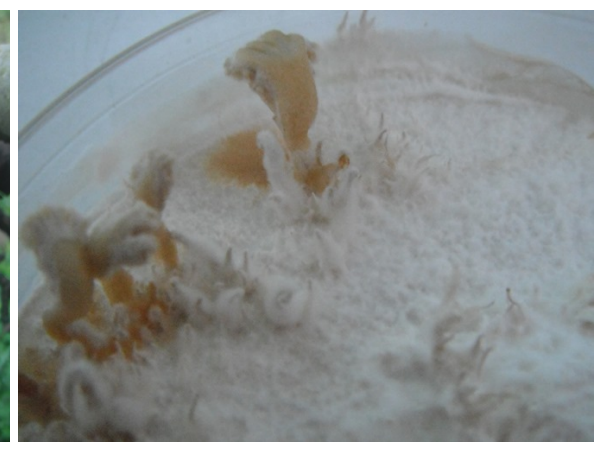

Figure 3

To cite this report: Lahbib A, Chattaoui M, Aydi N, Zaghouani H, Beldi O, Daami-Remadi M, Nasraoui B, 2016. First report of Schizophyllum commune associated with apple wood rot in Tunisia. New Disease Reports 34, 26. http://dx.doi.org/10.5197/j.2044-0588.2016.034.026 (c) 2016 The Authors This report was published on-line at www.ndrs.org.uk where high quality versions of the figures can be found. 